\title{
Bilateral Adrenal Lymphoma with Hypercalcemia : An Autopsy Case Report with a Review of the Literature
}

\author{
Sachiko Iwamizu-Watanabe ${ }^{1)}$, Tohru Asai ${ }^{2)}$ and Naoyoshi Mori ${ }^{1)}$
}

\begin{abstract}
We report here an unusual autopsy case of bilateral adrenal lymphoma showing symptoms associated with hypercalcemia and taking a fulminant clinical course. The serum of the patient had a titer of $40 \mathrm{pg} / \mathrm{ml}$ of intact parathyroid hormone (normal range : $10-65 \mathrm{pg} / \mathrm{ml}$ ) and a titer of $1720 \mathrm{pmol} / 1$ of parathyroid hormone-related protein $(\mathrm{PTHrP})$ (normal range : $13.8-55.3 \mathrm{pmol} / 1$ ). Autopsy revealed bilateral huge adrenal tumors, with the left weighing $230 \mathrm{~g}$, and measuring $12 \times 9 \times 3.5 \mathrm{~cm}$, and the right weighing $140 \mathrm{~g}$ and measuring $11 \times 8 \times 3 \mathrm{~cm}$. Histological examination revealed that the adrenal tumors were diffuse large cell lymphoma, and that the neoplastic cells were positive for CD20 (L26) and CD79a (mb-1). In addition, the neoplastic cells were positive for PTHrP mostly in the perinuclear space of the cells. In addition to the coma associated with hypercalcemia and acute renal failure, congestion and bronchopneumonia developed, leading to the death of the patient. There have been three case reports of bilateral adrenal lymphoma associated with hypercalcemia. Hypercalcemia should be checked carefully in the cases with adrenal lymphoma because it may result in fulminant clinical course.
\end{abstract}

Key Words bilateral adrenal lymphoma, hypercalcemia, parathyroid hormone-related protein (PTHrP)

\section{INTRODUCTION}

Autopsy series have indicated lymphomatous involvement in the adrenal glands in about $25 \%$ of the patients with lymphoma ${ }^{1,2}$. In contrast, the incidence of primary adrenal lymphoma is quite rare $^{3-5}$. Primary adrenal lymphoma tends to be predominant in males compared to females ( 2.5 to 7 times), occurs with an average age of 61 years (38$81)^{6}$, a morphology of large cell lymphoma and a B-cell phenotype with a small number of $\mathrm{T}$ cell phenotype ${ }^{3-6}$. Of the 70 cases with primary adrenal lymphoma reported so $\mathrm{far}^{3}$, bilateral cases constitute $70 \%$ of the total adrenal lymphomas. In the cases of adrenal lymphomas, symptoms may occur, due to the

Received: Aug 30, 2002

Revised: Nov 11, 2002

Accepted: Nov 20, 2002

1) Department of Pathology of Biological Response, Nagoya University Graduate School of Medicine, Nagoya, Japan

2) Internal Medicine of Nakatsugawa City Hospital, Nakatsugawa City, Japan

Address correspondence and reprint request to Naoyoshi Mori, Department of Pathology of Biological Response, Nagoya University Graduate School of Medicine, 65 Tsurumai-cho, Showa-ku, Nagoya 466-8550, Japan tumor itself or adrenal insufficiency. In the previous reports, there have been three cases of bilateral adrenal lymphoma showing hypercalcemia ${ }^{5}$. However, the cause of this symptom has not been discussed. We present here an unusual case with bilateral adrenal lymphoma showing hypercalcemia probably due to parathyroid hormone-related protein (PTHrP) produced by lymphoma cells.

\section{CASE REPORT}

\section{Clinical findings}

A 73-year-old female subject had a strange behavior in the last 6 months. The patient had been suffering from hypertension and slight degree of aortic valvular disease since 1987. She complained about memory disturbance and weakness for walking, gradually experienced incontinence and drowsiness, and was admitted to the emergency ward of the hospital. At the time of admission, computed tomography indicated that she had bilateral adrenal tumors, measuring $10 \mathrm{~cm}$ on the left and $8 \mathrm{~cm}$ on the right. Biochemical serum examination revealed 3386 IU/l of lactic dehydrogenase (LDH). She was 
admitted to the hospital for detailed examination.

Biochemical data at the time of admission were as follows; white blood cells, $7600 / \mu 1$; red blood cells, $417 \times 10^{4} / \mu 1$; hemoglobin, $12.1 \mathrm{~g} / \mathrm{dl}$; hematocrit, $36.3 \%$; platelets, $7 \times 10^{4} / \mu 1$; prothrombin time (PT), $13.6 \mathrm{sec}$; PT \%, $84 \%$; total protein, $6.0 \mathrm{~g} / \mathrm{dl}$; albumin, $4.1 \mathrm{~g} / \mathrm{dl}$; total bilirubin, $2.16 \mathrm{mg} / \mathrm{dl}$; glutamic oxaloacetic transaminase, $77 \mathrm{IU} / 1$; glutamic pyruvic transaminase, $41 \mathrm{IU} / 1$; LDH, 3386 IU/1; LDH isozyme (LDH1 26\%, LDH2 37\%, LDH3 26\%, LDH4 7\%, LDH5 4\%); alkaline phosphatase, $205 \mathrm{IU} / 1$; creatine phosphokinase, $169 \mathrm{IU} /$ $1 ; \mathrm{Na}, 141 \mathrm{mEq} / 1 ; \mathrm{K}, 2.7 \mathrm{mEq} / 1 ; \mathrm{Cl}, 96 \mathrm{mEq} / 1$; $\mathrm{Ca}, 27.2 \mathrm{mg} / \mathrm{dl}$; blood urea nitrogen (BUN), 32.0 $\mathrm{mg} / \mathrm{dl}$; creatinin $(\mathrm{Cr}), 1.3 \mathrm{mg} / \mathrm{dl}$; amylase, $351 \mathrm{U} /$ 1 ; CEA, $2.1 \mathrm{ng} / \mathrm{ml}$; CA19-9, $13.2 \mathrm{U} / \mathrm{ml}$; АCTH, $63 \mathrm{pg} / \mathrm{ml}$; antidiuretic hormone, $34.0 \mathrm{pg} / \mathrm{ml}$; cortisol, $29.5 \mu \mathrm{g} / \mathrm{dl}$; serum aldosterone, $48 \mathrm{pg} / \mathrm{ml}$; soluble interleukin-2 receptor, $4170 \mathrm{U} / \mathrm{ml}$, urinary vanillyl mandelic acid, $5.0 \mathrm{mg} /$ day, urinary homovanillic acid, $3.5 \mathrm{mg} /$ day; $17-\mathrm{KS}, 7.3 \mathrm{mg} /$ day, 17-OHCS, $17 \mathrm{mg} /$ day.

At the time of admission, she was in a drowsy state, unable to walk, and unable to speak clearly. Superficial lymph nodes were not palpable. In addition to the bilateral adrenal tumors, hypercalcemia, high serum titer of LDH, and metabolic alkalosis, were noticed. Hypercalcemia was considered to be the main cause of the drowsiness, inability to walk, and general weakness. Needle biopsy was not carried out because of the poor general condition. Administration of a large amount of physiological saline, elcatonin and pamidronate disodium was initiated to correct for hypercalcemia. Fever and oliguria declared. Japan coma scale value was II-200. Five days after the admission, the serum calcium level improved to $13.1 \mathrm{mg} / \mathrm{dl}$; however, respiratory condition deteriorated, with $\mathrm{PCO}_{2}$ 59, $\mathrm{PO}_{2}$ 80, PH 7.19, revealing combined acidosis. Tracheal intubation was then performed. She finally developed anuria and acute renal insufficiency (BUN, $160.6 \mathrm{mg} / \mathrm{dl}$; Cr, $5.2 \mathrm{mg} / \mathrm{dl}$ ). In spite of respiratory control with a respirator and fluid infusion, the high fever continued with gradually deteriorated consciousness, and she died 7 days after admission.

\section{Autopsy findings}

Autopsy was performed $12 \mathrm{~h}$ after the patient's death. Slight degree of general jaundice was observed, and marked edema was seen in both the upper and the lower extremities. Superficial lymph nodes were not palpable.

Bilateral adrenal glands were markedly enlarged; $230 \mathrm{~g}$ in weight, $12 \times 9 \times 3.5 \mathrm{~cm}$ in size at right and $140 \mathrm{~g}$ in weight, $11 \times 8 \times 3 \mathrm{~cm}$ in size at left (Fig. 1). Macroscopically, these tumors had capsules and were generally brown in color admixed with small and large yellow-white nodules. On the cut surface, the tumors were smooth and glistening and had several large and small white nodules. Histologically, the tumor showed monomorphous proliferation of large-sized lymphoid cells. The neoplastic cells were large in size with vesicular nucleus and coarse chromatin (Fig. 2). Several small nucleoli and ample cytoplasm were noticed.

Immunohistochemically, the neoplastic cells were positive for CD20 (L26) and CD79a (mb-1) (Dako, Copenhagen, Denmark), revealing a B-cell phenotype (Fig. 3). The neoplasitc cells were posi-

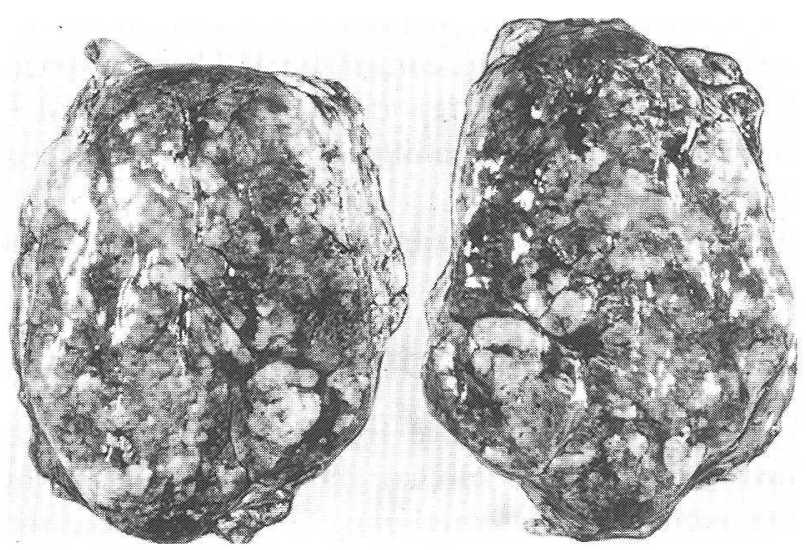

Fig. 1. Cut surface of bilateral adrenal lymphomas. Note the smooth and glistening surface with large and white nodules and dark red area accompanied by a severe congestion.

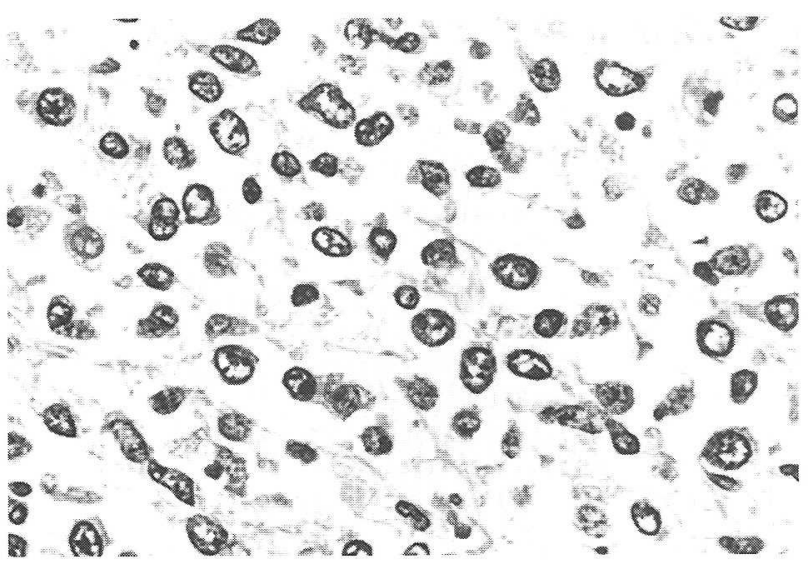

Fig. 2. H. E. staining. Large-sized lymphoma cells with round nucleus are observed. $\times 670$ 


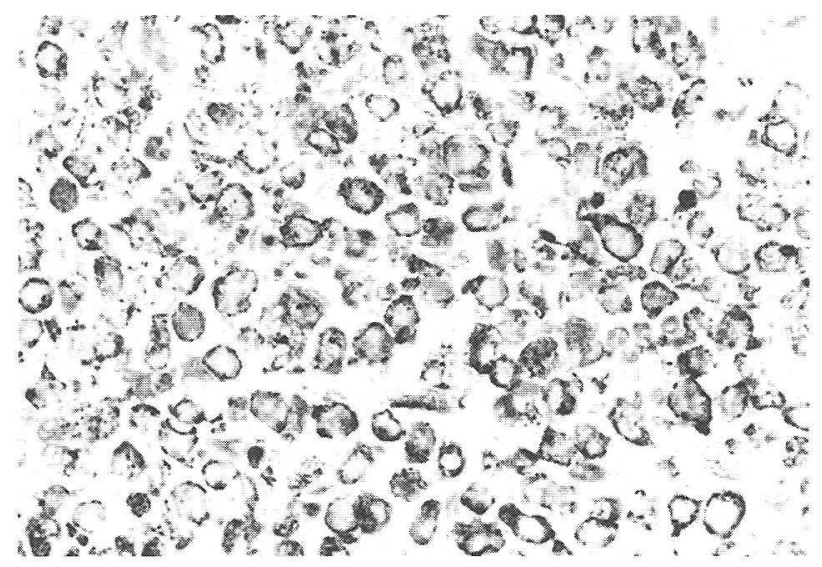

Fig. 3. Immunostaining for CD79a. Note the strong positive reactivity in the cytoplasm of the neoplastic cells. $\times 670$

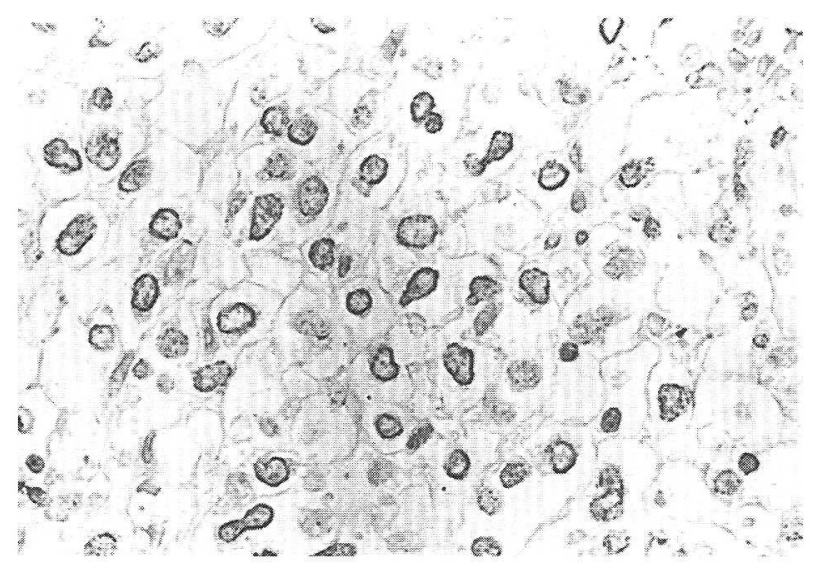

Fig. 4. Immunostaining for PTHrP. Positive reactivity is mainly observed in the perinuclear space of the neoplastic cells. $\times 670$

tive for PTHrP (Calbiochem, Cambridge, USA) in their perinuclear spaces and occasionally on the cytoplasmic membranes (Fig. 4). Admixed with the neoplastic cells, remaining adrenal cortical cells were occasionally observed, and necrosis and calcification were also noticed.

Lymphomatous involvement was not observed anywhere outside the bilateral adrenal glands including lymph nodes. Calcification was observed in renal tubules, and mitral and aortic valves. While the former was considered to have been caused by hypercalcemia, the latter might have been accompanied by artherosclerosis. The cause of the death of the patient was pulmonary edema concomitant with bronchopneumonia.

\section{DISCUSSION}

In the present case, severe hypercalcemia was observed at the biochemical examination, giving rise to various symptoms such as drowsiness, inability of walk, and general weakness. Blood examination performed at the time of autopsy revealed a normal level of intact parathyroid hormone (PTH) $(40 \mathrm{pg} /$ $\mathrm{ml}$; normal value: 10-65 $\mathrm{pg} / \mathrm{ml}$ ), but the PTHrP level was extremely high (1720 pmol/1; normal value: $13.8-55.3 \mathrm{pmol} / 1)$. At the time of the autopsy, lymphomatous metastasis was not observed outside the adrenal glands, including the bones. Therefore, we consider that hypercalcemia was caused by the production of PTHrP by the neoplastic cells, based on the high serum levels of PTHrP and the positive reactivity of the neoplastic cells for the PTHrP immunostaining.

Hypercalcemia is often noticed in the patients having malignant neoplasia in the course of the disease. In hematological malignancies, hypercalcemia was observed in patients with adult $\mathrm{T}$-cell leukemia/lymphoma (ATLL), multiple myeloma or malignant lymphoma in $23.5 \%, 26.7 \%$ and $5.6 \%$ of the cases respectively ${ }^{7}$. Hypercalcemia caused by malignant neoplasia is subclassified into local osteolytic hypercalcemia due to metastatic bone lesions and humoral hypercalcemia of malignancy (HHM) caused by the humoral agent produced by the neoplastic cells. Predominant cause of HHM is considered to be production of PTHrP. Of the malignant lymphomas, ATLL is well known as one of the PTHrP-producing tumors. Recent studies indicated that even in cases where the incidence of HHM is low in B-cell lymphomas, hypercalcemia is caused by PTHrP produced by the neoplastic cells ${ }^{8,9}$. Al-Fiar et $\mathrm{al}^{5}$. reported that three out of 17 cases of adrenal lymphomas, including the cases they studied, were accompanied by hypercalcemia. However, the cause of this symptom has not been discussed so far. Although the reason is still unknown, it is noteworthy that this lymphoma is frequently accompanied by hypercalcemia, including in this study.

PTHrP shares 8 out of the total 13 amino acid residues at the $\mathrm{N}$-terminus (63\%) in common with PTH. Also, PTHrP binds to the receptor (PTH/ PTHrP receptor) with almost the same affinity as $\mathrm{PTH}$, with a similar function. The PTH/PTHrP receptor is present in various organs of the body. In particular, it has an important role in the kidneys, where it enhances reabsorption of $\mathrm{Ca}$, and has en- 
Table 1. Summary of a literature review of bilateral adrenal lymphoma.

\begin{tabular}{|c|c|c|c|c|c|c|}
\hline Author & Age & Sex & Cell type & Treatment & Survival & Remarks \\
\hline Salvatore et al(3) & 27 & M & Large non-cleaved B-cell & $\mathrm{CHOP}$ & $\mathrm{CR}$ & \\
\hline Al-Fiar et al(5) & 61 & $\mathrm{~F}$ & Diffuse large cell & CHOP & 11 months & Hypercalcemia \\
\hline Yamamoto et al(12) & 63 & M & Diffuse large B-cell & $\begin{array}{l}\text { Surgery, } \\
\text { Chemo }\end{array}$ & $\mathrm{CR}$ & ITP \\
\hline Kuyama et al(13) & 69 & $\mathrm{~F}$ & Diffuse mixed B-cell & $\mathrm{CHOP}$ & $\mathrm{CR}$ & $\begin{array}{l}\text { Adrenal insuffi- } \\
\text { ciency }\end{array}$ \\
\hline Wu et al(14) & 64 & $\mathrm{~F}$ & $\begin{array}{l}\text { Large immunoblastic } \\
\text { B-cell }\end{array}$ & $\begin{array}{l}\text { Surgery, } \\
\text { Chemo }\end{array}$ & CR & \\
\hline Ellis et al(15) & 74 & $\mathrm{~F}$ & Diffuse B-cell & Chemo & 3 weeks & $\begin{array}{l}\text { Adrenal insuffi- } \\
\text { ciency }\end{array}$ \\
\hline Frankel et al(16) & 62 & $\mathrm{~F}$ & Anaplastic large cell & $\begin{array}{l}\text { Surgery, } \\
\text { Chemo }\end{array}$ & PR & EBER-ISH $(+)$ \\
\hline Hsu et al(17) & 64 & $\mathrm{~F}$ & Diffuse large B-cell & Chemo & 3 months & $\begin{array}{l}\text { Adrenal insuffi- } \\
\text { ciency }\end{array}$ \\
\hline Utsunomiya et al(18) & 72 & $\mathrm{~F}$ & Diffuse large B-cell & $\begin{array}{l}\text { Surgery, } \\
\text { Chemo }\end{array}$ & 12 months & $\begin{array}{l}\text { Adrenal insuffi- } \\
\text { ciency }\end{array}$ \\
\hline Hisano et al(19) & 77 & M & $\begin{array}{l}\text { Angioendotherial } \\
\text { lymphoma }\end{array}$ & Chemo, Rad & 6 months & \\
\hline Takahashi et al(20) & 66 & $\mathrm{~F}$ & Diffuse large B-cell & Chemo & 8 months & $\begin{array}{l}\text { Adrenal insuffi- } \\
\text { ciency }\end{array}$ \\
\hline Serrano et al(21) & 71 & M & Small cleaved cell & CHOP & $\mathrm{CR}$ & Addisonian crisis \\
\hline Prayson et al(22) & 69 & $\mathrm{~F}$ & Angiotrophic large cell & Steroid & & $\begin{array}{l}\text { Adrenal insuffi- } \\
\text { ciency }\end{array}$ \\
\hline Pagliuca et al(23) & 59 & M & High grade B-cell & MACOP-B & & $\begin{array}{l}\text { Adrenal insuffi- } \\
\text { ciency }\end{array}$ \\
\hline Abe et al(24) & 68 & M & $\begin{array}{l}\text { Diffuse small and large } \\
\text { cell }\end{array}$ & & & $\begin{array}{l}\text { BM \& PB involve- } \\
\text { ment }\end{array}$ \\
\hline Schnitzer et al(25) & 74 & M & T-cell immunoblastic & $\begin{array}{l}\text { I.T.Methotrex- } \\
\text { ate }\end{array}$ & & \\
\hline Shea et al(26) & 81 & M & Large cell & Steroid & 2 months & $\begin{array}{l}\text { Adrenal insuffi- } \\
\text { ciency }\end{array}$ \\
\hline Osei et al(27) & 55 & M & Diffuse large cell & & & \\
\hline Present case & 73 & $\mathrm{~F}$ & Diffuse large B-cell & & 9 days & Hypercalcemia \\
\hline
\end{tabular}

F, female; M, male; Chemo, chemotherapy; CHOP, cyclophosphamide, doxorubicin, vincristine, prednisone; Rad, radiation therapy; MACOP-B, methotrexate, doxorubicin, cyclophosphamide, vincristine, prednisone, bleomycin; I. T. methotrexate, Intrathecal methotrexate; PR, partial remission; CR, complete remission; ITP, idiopathic thrombocytopenic purpura; ISH, in situ hybridization; BM \& $\mathrm{PB}$, bone marrow \& peripheral blood

hanced osteolytic function ${ }^{9-11}$.

Symptoms accompanied by the production of PTHrP can be dependent on the degree of hypercalcemia or the speed of the onset of this symptom. In cases with hypercalcemia, regardless of the cause, weakness, depressive state, lack of attention, loss of appetite, nausea, vomiting, constipation, polyuria and polydypsia, reversible tubular dysfunction of the kidney, reduction of QT time, and arrythmia may occur. The patient in the present case had a serum calcium titer of $27.2 \mathrm{mg} / \mathrm{dl}$ at presentation, and coma or acute renal insufficiency declared, accompanied with hypercalcemia. Furthermore, the patient had congestion of lungs and bronchopneumonia, leading death.

Of the 70 cases with primary adrenal lymphoma reported so $\mathrm{far}^{3}$, bilateral cases constitute $70 \%$ of the total adrenal lymphomas ${ }^{4}(\text { Table 1) })^{3,5,12-27}$. Correct diagnosis of primary bilateral lymphoma were made rarely before death, and most of the cases were not treated. Although intensive chemotherapy were given to the patients diagnosed with primary adrenal lymphoma, response to the therapy was not excellent. Although one of the reasons for the poor prognosis is the older age of the patients, other causes are yet to be identified ${ }^{5}$. Our patient died 9 
days after the diagnosis of this lymphoma. However, in recent years, cases with long survival have been reported after performing chemotherapy or surgical extirpation ${ }^{12-14}$.

In conclusion, patients with primary adrenal lymphoma undergo a symptom free course and it takes a long time before correct diagnosis is made in most of the patients. Although quite rarely feasible as of today, correct diagnosis should be made early, and the patient should be treated as soon as possible to improve prognosis.

\section{REFERENCES}

1 Paling MR, Williamson BR : Adrenal involvement in non-Hodgkin lymphoma. AJR Am J Roentgenol 141: 303-305, 1983

2 Rosenberg SA, Diamond HD, Jaslowitz B : Lymphosarcoma : a review of 1269 cases. Medicine (Baltimore) 40: 31-84, 1961

3 Salvatore JR, Ross RS : Primary bilateral adrenal lymphoma. Leuk Lymphoma 34: 111-117, 1999

4 Wang J, Sun NC, Renslo R, Chuang CC, Tabbarah HJ, Barajas L, French SW: Clinically silent primary adrenal lymphoma: a case report and review of the literature. Am J Hematol 58 : 130-136, 1998

5 Al-Fiar FZ, Pantalony D, Shepherd F: Primary bilateral adrenal lymphoma. Leuk Lymphoma 27 : 543-549, 1997

6 Bauduer F, Delmer A, Le Tourneau A, Guettier G, Alexandre JH, Zittoun R, Bernadou A: Primary adrenal lymphoma. Acta Haematol 88: 213-215, 1992

7 Takahasi T, Hirokawa M, Kudo K, Takatsu H, Yoshida K, Miura A: Clinical studies on hematological malignancies accompanied by hypercalcemia. Rinsho Ketsueki 27: 2070-2077, 1986 (Japanese)

8 Kremer R, Shustik C, Tabak T, Papavasiliou V, Goltzman D : Parathyroid-hormone-related peptide in hematologic malignancies. Am J Med 100: 406411,1996

9 Saito O, Kurosu M, Ando Y, Kusano E, Asano Y : High PTHrP level induced hypercalcemia and acute renal failure in a multiple myeloma patient. Nippon Jinzo Gakkai Shi 42: 41-46, 2000 (Japanese)

10 Tanaka K, Shiraishi K, Sakamoto A, Jojima H, Masuchi K, Okubo Y, Tanaka M, Fuzimatsu Y, Fukahori S, Osabe S, Imamura Y, Honda J, Oizumi $\mathrm{K}$ : Serum levels of carboxyterminal propeptide of type I procollagen (PICP), cross-linked carboxyterminal telopeptide region of type I collagen (ICTP) and carboxyterminal parathyroid hormone-related protein (C-PTHrP) in hematological malignancies with bone lesions and hypercalcemia. Rinsho Ketsueki 39: 273-280, 1998 (Japanese)

11 Zeimer H, Firkin F, Grill V, Slavin J, Zhou H, Martin TJ: Assessment of cellular expression of parathyroid hormone-related protein mRNA and protein in multiple myeloma. J Pathol 192: 336341,2000

12 Yamamoto E, Ozaki N, Nakagawa M, Kimoto M : Primary bilateral adrenal lymphoma associated with idiopathic thrombocytopenic purpura. Leuk Lymphoma 35 : 403-408, 1999

13 Kuyama A, Takeuchi M, Munemasa M, Tsutsui K, Aga N, Goda Y, Kanetada K : Successful treatment of primary adrenal non-Hodgkin's lymphoma associated with adrenal insufficiency. Leuk Lymphoma 38 : 203-205, 2000

14 Wu HC, Shih LY, Chen TC, Chu SH, Tsai CC: A patient with bilateral primary adrenal lymphoma, presenting with fever of unknown origin and achieving long-term disease-free survival after resection and chemotherapy. Ann Hematol 78: 289-292, 1999

15 Ellis RD, Read D: Bilateral adrenal nonHodgkin's lymphoma with adrenal insufficiency. Postgrad Med J 76: 508-509, 2000

16 Frankel WL, Shapiro P, Weidner N: Primary anaplastic large cell lymphoma of the adrenal gland. Ann Diagn Pathol 4: 158-164, 2000

17 Hsu CW, Ho CL, Sheu WH, Harn HJ, Chao TY : Adrenal insufficiency caused by primary aggressive non-Hodgkin's lymphoma of bilateral adrenal glands : report of a case and literature review. Ann Hematol 78: 151-154, 1999

18 Utsunomiya M, Takatera $\mathrm{H}$, Itoh $\mathrm{H}$, Tsujimura $\mathrm{T}$, Itatani $\mathrm{H}$ : Bilateral primary non-Hodgkin's lymphoma of the adrenal glands with adrenal insufficiency: A case report. Acta Urol Jpn 38: 311314, 1992

19 Hisano C, Asano Y, Ohe K, Matsubara F, Okamoto O, Shiraishi G, Okubo H: Modified CHOP and radiation therapy in an aged patient with angioendothelial lymphoma]. Rinsho Ketsueki 35: 506510, 1994 (Japanese)

20 Takahashi T, Ishii S, Atsumi S, Mita H, Hayashi T, Adachi M, Hinoda Y, Toyoshima N, Imai K : Bilateral non-Hodgkin's lymphoma of the adrenal glands with adrenal insufficiency]. Rinsho Ketsueki 37 : 867-869, 1996 (Japanese)

21 Serrano S, Tejedor L, Garcia B, Hallal H, Polo JA, Alguacil $G$ : Addisonian crisis as the presenting feature of bilateral primary adrenal lymphoma. Cancer 71: 4030-4033, 1993

22 Prayson RA, Segal GH, Stoler MH, Licata AA, Tubbs RR: Angiotropic large-cell lymphoma in a 
patient with adrenal insufficiency. Arch Pathol Lab Med 115 : 1039-1041, 1991

23 Pagliuca A, Gillett DS, Salisbury JR, Basu RN, Mufti GJ : Bilateral adrenal lymphoma presenting as Addison's disease. Postgrad Med J 65 : 684-686, 1989

24 Abe J, Kaneko H, Takagi A, Umezu H : Primary adrenal lymphoma. Report of an autopsy case. Acta Pathol Jpn 38 : 929-939, 1988

25 Schnitzer B, Smid D, Lloyd RV : Primary T-cell lymphoma of the adrenal glands with adrenal insufficiency. Hum Pathol 17: 634-646, 1986

26 Shea TC, Spark R, Kane B, Lange RF: NonHodgkin's lymphoma limited to the adrenal gland with adrenal insufficiency. Am J Med 78: 711-714, 1985

27 Osei K, Falko JM, Pacht E, Wall R, Goldberg RF : Primary adrenal insufficiency manifesting as malignant lymphoma. Arch Intern Med 143: 1791-1792, 1983 